Copyright (C) 2014 by Academic Publishing House Researcher

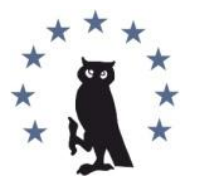

Published in the Russian Federation

European Researcher

Has been issued since 2010.

ISSN 2219-8229

E-ISSN 2224-0136

Vol. 81, No. 8-2, pp. 1546-1550, 2014

DOI: 10.13187/er.2014.81.1546

www.erjournal.ru

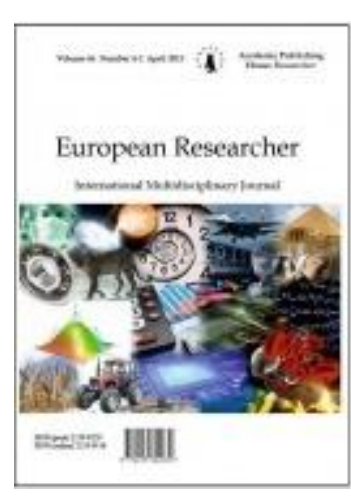

\title{
Problems and New Attitudes of Business Evaluation for M\&A in Kazakhstan
}

\author{
${ }^{1}$ Sanam S. Mirzaliyeva \\ ${ }^{2}$ Ilyas N. Rakhimzhanov
}

${ }^{1}$ International Educational Corporation, campus of Kazakh-American University, Kazakhstan Almaty, Toraygirova str. 29

$\mathrm{PhD}$, Associate Professor

E-mail: sanam-mirzalieva@mail.ru

${ }^{2}$ International Educational Corporation, campus of Kazakh-American University, Kazakhstan Almaty, Toraygirova str. 29

E-mail: ilyas32-33@mail.ru

\section{Abstract}

The main aim of the article is to look through the market of business evaluation for M\&A in Kazakhstan. Nowadays Kazakhstan is standing at the inception of the development of M\&A market; however, economy of country is rapidly growing, thus assuming a high level of knowledge and experience in M\&A issues. Therefore, new legislations are being applied; various methods and attitudes are starting to be used in cases of M\&A evaluation. For this reason, the topic is highly efficient for developing M\&A specialists and is as relevant as ever.

Keywords: Kazakhstan; mergers and acquisitions; development; attitudes; evaluation; economy; economic growth, legislation, business.

\section{Introduction}

Until recently, the market for mergers and acquisitions in Kazakhstan was inactive, but the growth and development of markets significantly raised the investment attractiveness of Kazakhstan. Our republic, as well as any country in the world, has its own characteristics, stages of development and background of mergers and acquisitions. Major drivers of the market of mergers and acquisitions in the Republic of Kazakhstan are high economic growth in the CIS, a good investment climate, rich raw material base. In this regard, topic is going to give consideration to a significant branch of development of our country - mergers and acquisitions market.

\section{Materials and methods}

The information and materials in the article are mainly based on legislations of evaluation and M\&A regulations, approved by Kazakhstan's Government, surveys and statistics from openaccess resources, as well as books and articles of Russian, Kazakhstan and other authors.

\section{Discussion}

In August 7, 1997 by the order of the Ministry of Labor and Social Protection of the Republic of Kazakhstan, qualifications for persons professionally engaged in the valuation of the property were approved; thereby the new profession "appraiser" was officially recognized [1]. 
Currently in Kazakhstan, relations arising from the valuation activities in order to establish market value of objects, defining the rights and responsibilities of evaluation activities - are governed by the Law of the Republic of Kazakhstan dated 3oth of November 2000 № 109 - II "On valuation activities in the Republic of Kazakhstan" (with alterations and amendments on 13.01.2014). Legislation of the Republic of Kazakhstan on the valuation activities is based on the Constitution of the Republic of Kazakhstan and consists of this Law and other legal acts of the Republic of Kazakhstan [2].

According to this Law, subjects of valuation are professional appraisers with specialized knowledge and skills, customers and third parties. Evaluators (or appraisers) are individuals who have the right to engage in evaluation activities, in accordance with the Act, on the basis of an employment contract with a legal entity engaged in valuation activities; either alone as a sole proprietorship under license in accordance with the legislation of the Republic of Kazakhstan "On Licensing" [3].

In the current conditions of high market competition, companies need to look for the most effective methods for business development, competitiveness, profitability and growth in value. Currently, one of the most effective ways to develop company - is to use strategy of mergers and acquisitions (M\&A). The implication of this strategy is the effect of synergy - excess of the cost of associated companies over their cost separately. This occurs as a result of elimination of overlapping functions and through access to new markets, new technologies, and improvement in organizational production cycle. There are two types of synergy: operational and financial. Operating synergies are advantages affecting the core activities of both companies (such as economies of scale and improvement of the ability to influence the price). This kind of synergy is usually manifested in increasing cash flow from the business. Financial synergy includes tax advantages, diversification, improvement of creditability, etc. This synergy can be shown in increasing cash flow and reduction of business risks [4].

One of the key steps in M\&A procedure is the estimation of the target company and the size of synergy. There are three evaluation approaches, which are mostly used in foreign practice:

- Profitable method;

- Costly method;

- Comparative method.

Comparative evaluation of the target company is compared to peers on various parameters. In this case, peers have a cost, as previously defined. Note the following disadvantages of this approach:

- Absolutely identical companies do not exist;

- Comparative approach does not allow to identify potential sources of synergy;

- Comparative approach cannot be applied to non-public companies.

The cost approach is based on the definition of the expenditure required for reproduction or replacement of the subject being evaluated, taking into account its wear. This approach ignores the value of intangible assets, which are typical for any business, which is why the definition of full-size synergy becomes impossible.

The main method of evaluation of M\&A is a profitable approach, which determines the cost based on estimates of future cash flows.

The income method involves the conventional division of the total period of the company into two periods: the period of forecasting and post-forecast period. It is assumed that during the forecast period there are significant changes in the company's operations and financial results (for example, strong growth in sales volumes). The terminal period begins after the stabilization of the financial performance of the company [5].

Nowadays, all these evaluation methods are starting to be used on the new growing field of M\&A in Kazakhstan, taking experience of international appraisers into account.

In Kazakhstan, the revival of the market of mergers and acquisitions began to happen a few years ago, when foreign investors have begun to show the most activity in acquiring assets in 
Kazakhstan, while currently the market of mergers and acquisitions in country is at an early stage of its development, having a great potential for further development.

Due to the fact that the companies, that are involved in the mining sector, have received much attention from foreign investors, because of high prices on oil and precious metals, as well as due to higher professional level of managers and improve of shareholder culture among local investors, it may be noted that State's M\&A market, acting in the role of the subject in these processes, does indirectly stimulate transactions in mergers and acquisitions.

Analyzing the specifics of this market, we can note the information secrecy of local companies, because for a business owner who wants to sell its assets, there is a risk of information leakage. So, in this kind of transaction, business owners are trying to carry out without the help of brokers or financial advisers, which is often problematic. There we can identify some problems such as: undeveloped share market - companies are still not transparent in terms of financial reporting and decision-making. Strong affiliation of the companies with financial-industrial groups is noticeable, and it is underdevelopment of effective corporate governance, plus a reluctance to change the situation $[1,6]$.

When market research analysts use different valuation techniques, they eventually figure that numbers in different companies can vary. However, the real market volumes significantly higher than current estimates of experts. So the main problem of objective analysis of this sector is its secrecy. Study affects only those transactions that have been committed officially from public disclosure. Basically, this applies only to large transactions, small and medium-sized businesses are not present in the annual reports.

Within a short period of development of M\&A market, it may be noted that the number of successful transactions in mergers and acquisitions in this country more than the world average, but this is often due to the fact that it is non-standard transaction. Most of them took place in an environment where the purchased asset is undervalued, due to, for example, political risks or adverse conditions while some assets were bought not at fair value (lack of assets evaluation).

Trend of rapid seizure of assets that is found in Kazakhstan, where companies do not come from motivation, consistent with the development strategy of its own, but rather from desire to capture as many resources as they can, to form conglomerates, which obsoletes with time. That's because this method of getting resources and construction of activities only through the expansion of assets - is not economically viable. Example of more developed countries will recur: eventually the principle of growth of conglomerates will held by the growth efficiency of existing assets and activities of its core activities [6].

Over the next few years, Kazakhstan expects another stage where economic laws will begin to work on a standard scenario, while the growth rate of the market won't reduce. Desire to expand markets or geographical expand, access to new financing - it will all remain the same. New rules set by market will zoom in our country to the world trend, where two thirds of transactions do not bring the companies increase in capitalization and make them pay attention to the internal factors of the merger.

In view of the fact that many sectors of Kazakhstan are in the early phase of its development, and companies are owned and operated by the owners, a large number of mergers are not observed, because usually merger is a transaction of equal to try to improve their competitiveness. These transactions often occur in the later stages of the industry growth and in a developed capital market. In Kazakhstan transactions primarily occur in format of "acquisitions".

Mergers and acquisitions market - is primarily a process of globalization, therefore, it is not surprising that in our country, the development of the market is held with a significant participation of foreign capital. Foreign investors set the good pace of market development, and its dynamic development in Kazakhstan will probably not abate in the future, and moreover, the market will evolve and expand - with the development of capital market, transactions will be more transparent. Public companies, that put their shares on the market, will provide more information about their selves, which can make them an object of interest for mergers and acquisitions [7].

In recent years, Kazakhstan has the growth of markets in almost all commodity groups, which, in particular, will cause the market to follow the Russian experience - new branches will be activated, in addition to oil production and mining sector.

In industries oriented to the consumer sector - retails, consumer goods production and the food industry has a very large potential. Analysts also see horizons in the service sector, hotel and 
the food industry which are now rapidly growing. In any case, M\&A is an important indicator of the evolution of business in our country and outside involvement in the processes of integration of Kazakhstan into global businesses.

In a very short time, retailers will develop in the regions, absorbing regional players. And after the industry the main part of the leaders will be formed, merger of major players will begin, entering Western chains on the market of Kazakhstan, by purchasing locals. Investors are attracted by absence of serious domestic constraints from powerful financial-industrial groups in the retail sector, services, infrastructure and construction.

The feature of Kazakhstan is a fragmentation of the market in most sectors. Taking retail as an example. There are no uniformed retailers network in Kazakhstan, just a few well presented in two or three cities - market presents a large number of disparate stores of various sizes, a set of goods and various standards. Buyer needs recognition and uniformity (for example Turkish retailers - "A101", "Şok", etc.). Therefore, the consolidation will increase. Growing consolidation in other market segments are not excluded as well.

The promising sector in this regard is the mining sector. Currently there are many small steel companies in Kazakhstan that produce zinc, gold, they all can be targeted for takeover. For all the major players in this sector, today's topical issue is diversification and the creation of large metallurgical holdings.

Since M\&A market is a good indicator of economic development and reflects the main trends occurring in it, the main interest of mergers and acquisitions are seen in industries such as oil and gas, mining, cement, telecommunications and financial industry. Most attractive for M\&A transactions are the objects of the fastest growing sectors of the economy in which there are a large number of players. For example, Chinese and Indian investors, followed by the U.S. and Russian investors, are very active in the acquisition of oil and gas companies and fields due to the huge struggle of the world's energy reserves $[6,7]$.

Recently, the Kazakh media began to pay attention to such problematic aspects of our economy and legal reality, as raiding - the seizure of power business, which migrates to us from other countries. If this phenomenon is not put serious barrier - irreversible consequences will occur, that will affect our external policy. In Britain, for example, there were only two companies were raid, after which the British House of Commons quickly passed a law, and two months later the House of Lords approved it, and there were no more incidents. Raiders - is a new issue for our business, which only began to rise from the knees and come out of the shadow [8].

Corruption involvement in the process of law enforcement agencies and the judiciary characterizes hostile takeovers in Kazakhstan. Today even Kazakhstan Law contains no definition of "illegal acquisition". There are no universal prescriptions to combat hostile takeovers, because each acquisition is unique.

Three main options of hostile takeovers developed in Kazakhstan:

- Control over the management of the enterprise or a person representing the interests of large shareholder;

- The acquisition of a control stake;

- Bankruptcy of the company, followed by the acquisition of its assets.

The raiding problem in Kazakhstan - as already noted, is mostly the problem of corruption and inadequate legislation.

To strengthen the role of law in preventing and efficient settlement of corporate conflicts, careful and meticulous work is required to improve Kazakhstan's corporate law (corporate governance), as well as procedural law [6].

According to experts, the complete ban of "hostile takeovers" by legislation method will lead to the fact, that shareholders of enterprises can become hostages to their managers, which generally have a negative impact on the economy of the state as a whole. Currently, this problem is particularly acute in large cities. After all, the aim of the process of mergers and acquisitions is to obtain control over the business as a whole or of the assets of the enterprise. It would be a mistake to believe that this goal is achieved only by consistent buying shares, bringing stake to a controlling share, changing management of enterprise, if necessary - reorganization or transactions aimed to the withdrawal of the Company's assets. This process is extremely time consuming and expensive, and this reduces its attractiveness to potential investors, and in order to avoid this time-consuming procedure, many methods and schemes are used in practice, which are not connected with the 
criminal law topics, and are based on current corporate law, partly by his problematical and contradictory [9].

\section{Conclusion}

Analysis of mergers and acquisitions market revealed the following problems of development in Kazakhstan:

- "Super-concentration" of the property - the largest shareholders are trying to secure a stake of at least $75 \%$;

- Underdeveloped institutions of professional consultants in the market, the role of which is operated primarily overseas by investment banks;

- Reluctance of the public, and in many ways the environmental authorities to learn to distinguish professional from criminal who uses the cover;

- The problem of the existence of "raids";

- Absence of legislative developments;

- Opacity information about many domestic transactions;

- Local investors usually do not use the services of experienced financial and legal experts in the process of negotiating [7].

In the future, the growth of mergers and acquisitions in the banking sector and underdeveloped sectors is expected. The banking sector will be reduced by decresing the number of small banks. Undeveloped sector can begin to develop, if the foreign companies absorb them, or if they begin to merge with each other.

In the end, Kazakhstan will repeat the development of this market by foreign experience when conglomerates will not want to spend money on mergers and acquisitions, but will be developed by increasing domestic productivity.

\section{References:}

Сыздыкова Э.Ж., Шакенова Г.А. Посткризисные ориентиры социально-экономические и инновационного развития Казахстана. Караганда, 2010, С. 12-13

Закон Республики Казахстан от 30 ноября 2000 года № 109-II «Об оценочной деятельности в Республике Казахстан»

\section{Закон Республики Казахстан от 11 января 2007 года № 214-III «О лицензировании»}

Бодров К., Шахова Д. М\&А: Оценка в целях слияния и поглощения. [Электронный pecypc] //CMAO, URL: http://smao.ru/ru/company/contact.html (дата обращения 7.08.2014)

Brian Coyle. Mergers and Acquisitions. Global Professional Publishing. 2000, 140 p.

Касимова М., Галижапаров А., Жимайлова Б., и др. Научно - исследовательская работа в рамках программы «Жас Ғылым», Павлодарский государственный университет им. С. Торайгырова, 2009, 51 с.

Салихова А. Рост без неожиданностей // Эксперт РА Казахстан. №22, 3-9 июнь 2013 г. [Электронный ресурc] URL:http://www.raexpert.kz/ (дата обращения 7.08.2014)

Грачев В.А. Враждебные поглощения: Типология и способы защиты. //Акционерное общество: вопросы корпоративного управления. №7 июль 2006г. [Электронный ресурс] URL:http://www.advisers.ru/file/advisers/Vrag_pogl.pdf (дата обращения 5.08.2014)

Ryngaert M. The Effect of Poison Pill Securities on Shareholder Wealth. Journal of Financial Economics, University of Florida, USA, 1988 